\title{
En kvinne med tilbakevendende urticaria, leddsmerter og feber
}

\author{
En kvinne var i mange år plaget av tilbakevendende urticaria ledsaget \\ av feber, og senere ledd- og muskelsmerter. Noen bakenforliggende \\ årsak ble ikke funnet. Etter 13 års sykdom ble det påvist en sjelden \\ tilstand.
}

Se kommentar side 137 og kunnskapsprøve på www.tidsskriftet.no/quiz

\section{Jan Tore Gran \\ jan.tore.gran@rikshospitalet.no \\ Øyvind Midtvedt \\ Revmatologisk seksjon \\ Sidsel Haug \\ Seksjon for hudsykdommer}

Oslo universitetssykehus, Rikshospitalet 0027 Oslo

En 52 år gammel, tidligere frisk kvinne oppsøkte sin fastlege på grunn av tilbakevendende generalisert utslett. Hun brukte ingen medisiner. Hun var ikke plaget av kløe, og utslettet etterlot ikke arr. Episodene varte den første tiden bare noen få timer, og imellom disse var hun helt frisk. Fastlegen henviste pasienten til privatpraktiserende hudlege som stilte diagnosen kronisk tilbakevendende urticaria. En omfattende allergiutredning ga ingen avklaring av årsaksforholdene. Hun ble behandlet med forskjellige antihistaminer og UV-B-lys uten at dette endret plagene vesentlig. Andre behandlingstiltak ble ikke iverksatt, og pasienten ble fulgt opp av fastlegen.

Med årene ble de symptomfrie periodene kortere, og etter noen år hadde hun utslett nesten kontinuerlig. Utbredelsen og utseendet av utslettet endret seg ikke. Hun merket også at utslettet ble verre ved soleksponering, og hun begynte å bli plaget av generelle ledd- og muskelsmerter. I lange perioder hadde hun feber opp mot $39^{\circ} \mathrm{C}$. Fastlegen påviste også leukocytose og trombocytose (verdier ukjente), men dette ble ikke utredet videre. Det ble ikke observert leddhevelse forenlig med perifer artritt, symptomer tydende på infeksjonssykdom, eller muskelsvakhet. Det ble ikke påvist antinukleære antistoffer (ANA), eller antinøytrofilt cytoplasmatisk antistoff (ANCA). Ni år etter sykdomsstart henviste fastlegen pasienten til ny undersøkelse hos privatpraktiserende hudlege som bekreftet diagnosen urticaria. Det ble ikke funnet bakenforliggende allergi som kunne forklare det tilbakevendende utslettet. $H R$ (histamin release)-test var negativ og serumkonsentrasjonen av IgE innen normalområdet. Pasienten ble behandlet under diagnosen kronisk urticaria av ukjent årsak med antihistaminer uten tilfredsstillende effekt. Hun ble fulgt opp av fastlege og hudlege.

Utredningen ga ingen forklaring på årsaken til pasientens urticaria. Denne type utslett kan være en manifestasjon av systemisk bindevevssykdom, men verken ANA eller ANCA kunne påvises i serum. Utslett som forverres ved soleksponering, ses blant annet ved systemisk lupus erythematosus (SLE), men fraværet av symptomer fra indre organer og negativ test for ANA talte imot en slik årsaksforklaring. Fotosensitivt utslett opptrer ved dermatomyositt, men pasienten hadde ingen muskelsvakhet eller symptomer på lungesykdom som kunne gi mistanke om inflammatorisk myopati. Nivået av muskelenzymer i serum (kreatinkinase) er som oftest forhøyet ved inflammatoriske myopatier, men dette ble ikke analysert. Pasienter med dermatomyositt har heller ikke episodiske symptomer. De stadig tilbakevendende feberepisodene og leddsmertene kunne gi mistanke om autoinflammatorisk sykdom (familiær middelhavsfeber, tumornekrosefaktor-reseptorassosiert periodisk syndrom, Muckle-Wells' syndrom). De manglende funn av artritt, symptomer fra indre organer og pasientens alder støttet ikke disse diagnosene. De tilbakevendende feberepisodene sammen med leukocytose kunne gi mistanke om Stills sykdom med debut i voksen alder (adult Stills sykdom), men denne diagnosen ble ikke vurdert. Disse pasientene har imidlertid ofte artritt, serositt, og faryngitt hvilket ikke var til stede hos denne pasienten. Dessuten er utslettet ved adult Stills sykdom mer lakserosa av farge og mer flyktig enn de hudlesjonene som pasienten oppviste. Mange pasienter med adult Stills sykdom har forhøyet serum-ferritinnivå, men dette ble ikke analysert. Pasienten ble obser- vert videre av fastlege og hudlege under diagnosen kronisk urticaria av ukjent årsak.

13 år etter at pasienten oppsøkte fastlege første gang, ble hun henvist til regionsavdeling for hudsykdommer. Utslettet var nå nesten kontinuerlig til stede. Ved undersøkelsen her fant man erytematøse, lett eleverte og hovedsakelig annulære lesjoner. Utslettet var mest uttalt på bryst, rygg og armer. SR var $51 \mathrm{~mm} / \mathrm{t}(1-17 \mathrm{~mm} / \mathrm{t})$, trombocytter $751 \cdot 10^{9} / 1\left(165-387 \cdot 10^{9} / \mathrm{l}\right)$, og leukocytter $16,5 \cdot 10^{9} / l\left(3,6-9,3 \cdot 10^{9} / l\right)$. Test for antinukleære antistoffer var fortsatt negativ. Hudbiopsi viste lett perivaskulær betennelse med nøytrofile og eosinofile leukocytter, men ingen tegn til vaskulitt. Immunfluorescens av hud viste ingen immunnedslag. På grunn av ledd-og muskelplager ble pasienten henvist til revmatolog, som ikke fant holdepunkter for betennelsesaktig revmatisk sykdom. Serumelektroforese viste en monoklonal komponent av type IgM (kappabånd, 1-2 g/l), og man mistenkte malign myeloproliferativ eller lymfoproliferativ lidelse. Beinmargsbiopsi viste $10 \%$ plasmaceller, men en vurdering av hematolog konkluderte med at det ikke forelå holdepunkter for malign sykdom. Ved en beinmargsbiopsi to år senere ble det heller ikke funnet tegn til malign sykdom, og antallet plasmaceller sank senere til $3 \%$. Ved røntgenundersøkelse av lunger ble det funnet fibrotiske forandringer og emfysem, sannsynligvis betinget i mangeårig sigarettrøyking. Skjelettscintigrafi viste kun degenerative forandringer. Pasienten ble fulgt opp poliklinisk av hudlege og behandet med leukotrienantagonist som ga noe effekt i form av blekere utslett. Pasientens kroniske urticaria ble også forsøkt behandlet med ciklosporin A $200 \mathrm{mg}$ daglig uten at plagene endret seg.

Ved utredning hos revmatolog og hudlege hadde man så langt det var mulig utelukket betennelseaktig revmatisk sykdom, allergisk sykdom og malign myeloproliferativ og lymfoproliferativ lidelse. Kombinasjonen kronisk urticaria, artralgier, myalgier, tilbakevendende feber, akuttfaserespons, og monoklonal gammopati var imidlertid mest forenlig med Schnitzlers syndrom.

Etter anbefaling fra revmatolog ble det besluttet å gjøre et behandlingsforsøk med IL1-reseptorantagonisten anakinra $100 \mathrm{mg}$ daglig subkutant. Ved start av behandlingen 
hadde pasienten vedvarende urtikarielt ut slett (fig 1), smerter i skjelett og ledd, myalgier, daglig feber og uttalt sykdomsfølelse. Pasienten rapporterte telefonisk betydelig bedring allerede 1-2 dager etter behandlingsstart. Ved kontroll 14 dager senere fant man ingen tegn til utslett, og hun hadde ingen leddplager eller feber. Ved siste kontroll, ti måneder etter påbegynt behandling med anakinra var pasienten fremdeles symptomfri. Hennes monoklonale gammopati var uendret. Pasienten følges nå opp med halvårige kontroller hos revmatolog, og behandlingen må sannsynligvis fortsette $i$ mange år.

\section{Diskusjon}

Schnitzlers syndrom ble først beskrevet av den franske legen Lorette G. Schnitzler i 1972 (1). Syndromet består av urtikarielt utslett og monoklonal IgM-komponent samt to av åtte andre manifestasjoner (tab 1) (2). Schnitzlers syndrom forekommer oftere hos kvinner enn hos menn og starter som regel i 50 -årene (1). Hos færre enn $10 \%$ inntreffer sykdomsstart før 35-årsalderen (1). Hos vår pasient startet sykdommen da hun var i begynnelsen av 50-årene. Tilbakevendende urticaria er som regel det første symptom på syndromet. Vår pasient hadde dette i mange år før andre symptomer utviklet seg. Videre ses anfallsvis feber hos nesten $90 \%$ og leddsmerter hos $80 \%$ (1). Dette var fremtredende symptomer hos vår pasient. Andre relativt hyppige manifestasjoner er vist $\mathrm{i}$ tabell 1. Mer sjeldne manifestasjoner er kronisk inflammatorisk demyeliniserende polynevropati, pseudoxanthoma elasticum, hodepine, depresjon og vertigo, men disse ble ikke sett hos den aktuelle pasienten.

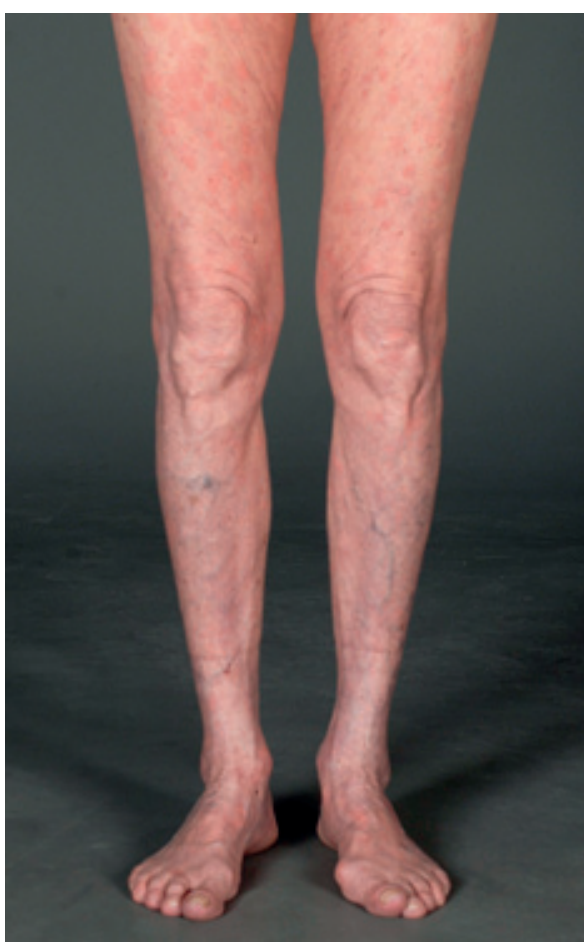

Figur 1 Urtikarielt utslett
Som oftest påvises monoklonalt $\operatorname{IgM}$, men dette behøver ikke være til stede i starten av sykdommen (1). Vi vet ikke når vår pasient utviklet monoklonal gammopati da dette ble undersøkt første gang og påvist 13 år etter sykdomsstart. Det er beskrevet Schnitzlers syndrom uten monoklonal komponent, men dette forekommer sannsynligvis hos under $5 \%$ av pasientene (3). De fleste pasienter med Schnitzlers syndrom har lette kjeder av kappatype, og Bence Jones' proteinuri kan påvises hos omkring en firedel (1). Rundt $15 \%$ vil utvikle malign sykdom, oftest i form av Waldenströms makroglobulinemi $(1,4)$. 15-årsoverlevelse er beregnet til over $90 \%$ ved Schnitzlers syndrom (1). De patofysiologiske mekanismene ved Schnitzlers syndrom er fortsatt uavklarte, men sannsynligvis skjer det en aktivering av NALP-inflammasom som så fører til økt produksjon av IL-1. Den sentrale rollen som IL-1 spiller i sykdomsutviklingen, kommer tydelig frem ved den frapperende effekten av behandling med IL1-reseptorantagonister. Hos flere av pasientene med slikt syndrom kan det påvises IgGantistoff rettet mot nettopp IL-1 (5). En mulighet er at disse antistoffene forlenger halveringstiden av IL-1 med økte nivåer som følge. Hvorfor pasienter med økt IL-1-aktivitet har økt risiko for å utvikle monoklonal gammopati, har man imidlertid ingen fullgod forklaring på (6).

Schnitzlers syndrom er en kronisk tilstand, og spontane remisjoner er ikke rapportert. Behandlingsmessig representerer syndromet en utfordring. Antihistaminer har som regel ingen effekt, og perorale kortikosteroider gir effekt hos under halvparten av pasientene (1). Vår pasient hadde liten eller ingen effekt av antihistaminer, UV-B-lys, eller ciklosporin. I den senere tid er det kommet kasuistiske meddelelser om effekt av IL-1-reseptorantagonisten anakinra på både feber og utslett $(7,8)$. Hos vår pasient forsvant alle sykdomsmanifestasjoner rett etter påbegynt behandling med anakinra. De fleste rapportene om behandling med anakinra ved Schnitzlers syndrom angir at effekten inntreffer i løpet av timer til noen få dager. Imidlertid vender symptomene hos de fleste tilbake ved dosereduksjon, eller seponering av anakinra. Effekten ved gjenopptatt behandling etter en kortvarig behandlingsstopp er oftest meget god. Det er ukjent om behandling med anakinra kan forebygge komplikasjoner som for eksempel overgang til lymfoproliferativ sykdom. Om man på sikt kan forlenge intervallene mellom hver injeksjon av anakinra uten å miste effekt er også ukjent.

Behandling med biologiske medikamenter er kostbart, og ett års bruk av anakinra vil koste omkring $100000 \mathrm{kr}$. Man har ved anakinra fått et behandlingsalternativ som kan spare pasientene for utprøving av andre mindre effektive og ofte kostbare behandlinger. Selv om Schnitzlers syndrom er en meget sjelden tilstand, bør diagnosen overveies
Tabell 1 Relativt hyppige manifestasjoner av Schnitzlers syndrom

Urtikarielt utslett

Monoklonal IgM-komponent og to av følgende:

Feber

Artralgi eller artritt

Beinsmerter

Lymfadenopati

Hepato- eller splenomegali

Leukocytose

Forhøyet SR

Abnormitet ved beinmorfologisk undersøkelse

hos pasienter med tilbakevendende urtikarielt utslett, spesielt hvis dette er ledsaget av feber og leddsmerter. Slike pasienter bør følges nøye med tanke på utvikling av monoklonal gammopati, eventuelt med overgang til malign sykdom. Pasientene bør henvises revmatolog for vurdering av behandling med IL-1-reseptorantagonister.

Pasienten har gitt samtykke til at artikkelen blir publisert.

Oppgitte interessekonflikter: Ingen

\section{Litteratur}

de Koning HD, Bodar EJ, van der Meer JWM et al. Schnitzler syndrome: beyond the case reports: review and follow-up of 94 patients with an emphasis on prognosis and treatment. Semin Arthritis Rheum 2007: 37: 137-48.

2. Lipsker D, Veran Y, Grunenberger F et al. The Schnitzler syndrome. Four new cases and review of the literature. Medicine (Baltimore) 2001; 80 $37-44$.

3. Varella TC, Nishimura MY, Machado MC et al. Schnitzler's syndrome without monoclonal gammopathy. Acta Derm Venereol 2005; 85: 272-3.

4. Lim W, Shumak KH, Reis M et al. Malignant evolution of Schnitzler's syndrome-chronic urticaria and IgM monoclonal gammopathy: report of a new case and review of the literature. Leuk Lymphoma 2002; 43: $181-6$.

5. Saurat JH, Schifferli J, Steiger $\mathrm{G}$ et al. Anti-interleukin-1 alpha autoantibodies in humans: characterization, isotype distribution, and receptor binding inhibition-higher frequency in Schnitzler's syndrome (urticaria and macroglobulinemia). J Allergy Clin Immunol 1991: 88: 244-56.

6. Almerigogna F, Giudizi MG, Cappelli $F$ et al. Schnitzler's syndrome: what's new? J Eur Acad Dermatol Venereol 2002; 16: 214-9.

7. Dybowski F, Sepp N, Bergerhausen HJ et al. Successful use of anakinra to treat refractory Schnitzler's syndrome. Clin Exp Rheumatol 2008, 26: $354-7$

8. Besada E, Nossent H. Dramatic response to IL1RA treatment in longstanding multidrug resistant Schnitzler's syndrome: a case report and literature review. Clin Rheumatol 2010; 29: 567-71.

Manuskriptet ble mottatt 16.3. 2010 og godkjent 19.8. 2010. Medisinsk redaktør Lars Frich. 